Abstract 353 Table 1 Sociodemographic and clinical characteristics of the SLE patients

\begin{tabular}{|c|c|c|c|}
\hline \multicolumn{2}{|c|}{ Characteristic } & Median & IQR \\
\hline \multicolumn{2}{|c|}{ Age (vears) } & $\overline{47}$ & 23 \\
\hline \multicolumn{2}{|c|}{ Educzional level } & $\pi$ & 7 \\
\hline & & \multicolumn{2}{|c|}{$\frac{1}{\%}$} \\
\hline \multicolumn{2}{|c|}{ Gender (Female) } & \multicolumn{2}{|c|}{92,1} \\
\hline Avea & Urban & \multicolumn{2}{|c|}{91} \\
\hline \multirow[t]{7}{*}{ Ocupasion } & Student & \multicolumn{2}{|c|}{5,6} \\
\hline & Unemployed & \multicolumn{2}{|c|}{3.6} \\
\hline & Rouse mad & \multicolumn{2}{|c|}{41,2} \\
\hline & Retred & \multicolumn{2}{|c|}{10,6} \\
\hline & Intelectual & \multicolumn{2}{|c|}{10,3} \\
\hline & Manual & \multicolumn{2}{|c|}{20,1} \\
\hline & Moed occupation & \multicolumn{2}{|c|}{8,6} \\
\hline \multirow{5}{*}{$\begin{array}{l}\text { Socioeconomical } \\
\text { status }\end{array}$} & 1 & \multicolumn{2}{|c|}{11,5} \\
\hline & 2 & \multicolumn{2}{|c|}{36,8} \\
\hline & 3 & \multicolumn{2}{|c|}{36,4} \\
\hline & 4 & \multicolumn{2}{|c|}{10,8} \\
\hline & $\overline{506}$ & \multicolumn{2}{|c|}{4,5} \\
\hline & calmanifestat & & \\
\hline
\end{tabular}

\begin{tabular}{|c|c|c|}
\hline \multirow[t]{3}{*}{ Age at onset } & Early (<20 years) & $\overline{16,3}$ \\
\hline & Moderate (20-50 years) & $\overline{66,6}$ \\
\hline & Late (250 years) & 17,1 \\
\hline \multirow{5}{*}{$\begin{array}{l}\text { Cardiovascular } \\
\text { disease }\end{array}$} & Any cause & 31,6 \\
\hline & Atteria hypertension & 28,6 \\
\hline & Thrombosis & 29 \\
\hline & Carebrovascular disease & 1,9 \\
\hline & Coconary artery disease & 1,2 \\
\hline \multicolumn{2}{|l|}{ Organ damage } & 34.9 \\
\hline \multicolumn{2}{|l|}{ Polyautoimmunity } & $\overline{11,2}$ \\
\hline \multicolumn{2}{|c|}{ Acute activity by SLEDAI } & $\overline{11,1}$ \\
\hline \multicolumn{2}{|c|}{ 6-months clinical remission } & 752 \\
\hline
\end{tabular}

methodology of the study and its limitations, it is not possible to conclude a causal relationship. More studies must be done to clarify the influence of coffee in autoinmune disease.
Abstract 353 Table 2 Association between coffee consumption and clinical outcomes in SLE patients $(\mathrm{N}=731)$

\begin{tabular}{|c|c|c|c|c|c|c|c|}
\hline \multirow[t]{2}{*}{ Characteristic } & & \multicolumn{2}{|c|}{$\begin{array}{c}\text { Coffee } \\
\text { consumptio } \\
n\end{array}$} & \multirow[t]{2}{*}{$\begin{array}{l}\text { Chi- } \\
\text { square }\end{array}$} & \multirow[t]{2}{*}{ Pvalue } & \multirow[t]{2}{*}{ OR } & \multirow[t]{2}{*}{$95 \% \mathrm{Cl}$} \\
\hline & & Yes & No & & & & \\
\hline \multirow[t]{3}{*}{ Age at onset } & Early & 73 & 46 & \multirow{3}{*}{5,25} & \multirow{3}{*}{0,072} & 0,57 & $0,33 \cdot 0,97$ \\
\hline & $\begin{array}{c}\text { Moder } \\
\text { ate }\end{array}$ & 346 & 141 & & & 0,88 & $0,56-1,37$ \\
\hline & Late & 92 & 33 & & & 1 & . \\
\hline \multirow{2}{*}{$\begin{array}{c}\text { Cardiovascular } \\
\text { disease }\end{array}$} & Yes & 148 & 83 & \multirow{2}{*}{5,46} & \multirow{2}{*}{$0,019^{\circ}$} & 0,67 & $0,48 \cdot 0,93$ \\
\hline & No & 363 & 137 & & & 1 & $\cdot$ \\
\hline \multirow[t]{2}{*}{ Organ damage } & $\overline{Y e S}$ & 184 & 71 & \multirow{2}{*}{0,94} & \multirow{2}{*}{0,335} & $\overline{1,18}$ & $0,84 \cdot 1,65$ \\
\hline & No & 327 & 149 & & & 1 & . \\
\hline \multirow{2}{*}{$\begin{array}{l}\text { Polyautoimmu } \\
\text { nity }\end{array}$} & $\overline{\text { YeS }}$ & 58 & 24 & \multirow{2}{*}{0,03} & \multirow{2}{*}{0,86} & & $0,63 \cdot 1,73$ \\
\hline & No & 453 & 196 & & & 1 & . \\
\hline \multirow{2}{*}{$\begin{array}{l}\text { Acute activity } \\
\text { by SLEDAI }\end{array}$} & $\overline{Y e s}$ & 52 & 29 & \multirow{2}{*}{1,41} & \multirow{2}{*}{0,23} & $\overline{0,74}$ & $0,46 \cdot 1,21$ \\
\hline & No & 459 & 191 & & & 1 & . \\
\hline \multirow{2}{*}{$\begin{array}{l}6 \cdot \text { months } \\
\text { clinical } \\
\text { remission }\end{array}$} & $\overline{\text { Yes }}$ & 396 & 154 & \multirow[b]{2}{*}{4,64} & \multirow[b]{2}{*}{$0,031^{\circ}$} & 1,48 & $1,03 \cdot 2,10$ \\
\hline & No & 115 & 66 & & & 1 & . \\
\hline
\end{tabular}

\section{A COMPARATIVE ANALYSIS OF GUT MICROBIOTA BETWEEN SYSTEMIC LUPUS ERYTHEMATOSUS PATIENTS AND NON-AUTOIMMUNE CONTROLS: A SINGLE CENTRECENTER COHORT EXPERIENCE}

${ }^{1} \mathrm{~A}$ bankole*, ${ }^{2} \mathrm{X}$ Luo, ${ }^{2} \mathrm{Z}$ Husen. ${ }^{1}$ Carilion Clinic, Rheumatology, Roanoke, USA; ${ }^{2}$ Virginia Tech, Department of Biomedical Sciences and Pathobiology, Blacksburg, USA

\subsection{6/lupus-2017-000215.354}

Background and aims Systemic lupus erythematosus (SLE) is the prototypical systemic autoimmune disease, and is characterised by hyperactive immune cells and antibody production. Change in gut microbiota is associated with autoimmune diseases in animal and humans models. We hypothesised that similar changes would be seen in patients with lupus, and may be future therapeutic targets.

Methods 21 patients with SLE and 12 controls with no autoimmune disease were enrolled. Stool samples obtained, homogenised and the cells lysed with $0.1 \mathrm{~mm}$ sterile zirconia beads and a bead-beater. The DNA was extracted; V4 region of $16 \mathrm{~S}$ rRNA gene was amplified using PCR. The purified amplicons were sequenced bi-directionally. High-quality reads with Phred score of $\geq 20$ were obtained by using Quantitative Insights into Microbial Ecology. Chimeric sequences were identified with USEARCH and removed from analysis. Taxonomy was 


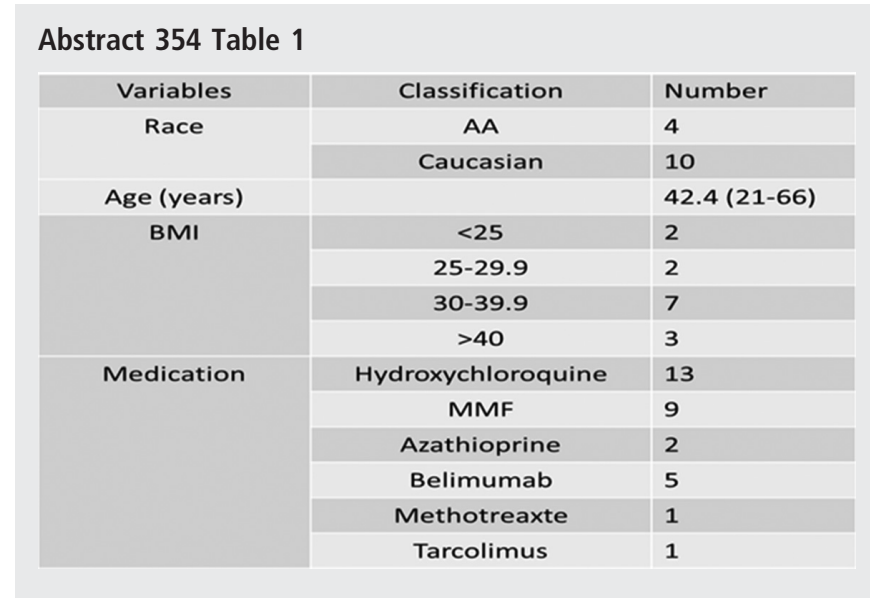

Abstract 354 Table 2
\begin{tabular}{|l|l|l|l|}
\hline Unregulated Bacteria & Pvalue & Down regulated Bacteria & Pvalue \\
\hline Phylum: Proteobacteria & 0.019 & Family: Christensenellaceae & 0.023 \\
\hline Family: Lachnospiraceae & 0.001 & Family: Odoribacteraceae & 0.008 \\
\hline Genus: Blautia & 0.005 & Family: Peptococcaceae & 0.03 \\
\hline Genus: Dorea & 0.032 & Family: Rikenellaceae & 0.005 \\
\hline Genus: Ruminococcus & 0.006 & & \\
\hline Family: Erysipelotrichaceae & 0.04 & & \\
\hline
\end{tabular}

assigned by using a naive Bayes classifier trained with the Greengenes taxonomy.

Results In the SLE patients, Proteobacteria phylum was up regulated. The Lachnospiraceae family was not significantly different based on $16 \mathrm{~S}$ rRNA sequencing. It was however significantly up regulated on quantitative PCR analysis.

The genera of Blautia, Dorea and, Ruminococcus in the Lachnospiraceae family were also significantly up regulated in the lupus.

The bacterial family of Erysipelotrichaceae was also significantly up regulated.

Rikenellaceae, Odoribacteraceae, Christensenellaceae and Peptococcaceae families were all significantly down regulated in Lupus.

Conclusions There were significant changes in gut microbiota between SLE and the control patients. The findings are similar to those reported in animal and human models with lupus and other autoimmune diseases.

\section{A COMPARATIVE STUDY OF VITAMIN D LEVELS IN AUTOIMMUNE AND NON-AUTOIMMUNE DISEASE}

${ }^{1} \mathrm{~A}$ bankole*, ${ }^{2} \mathrm{~F}$ Wong, ${ }^{2} \mathrm{~S}$ Ford, ${ }^{2} \mathrm{~J}$ McMunn, ${ }^{2} \mathrm{Z}$ Shahrear, ${ }^{2} \mathrm{~J}$ rawlins. ${ }^{1}$ Carilion Clinic, Rheumatology, Roanoke, USA; ${ }^{2}$ Carilion Clinic, Internal Medicine, Roanoke, USA
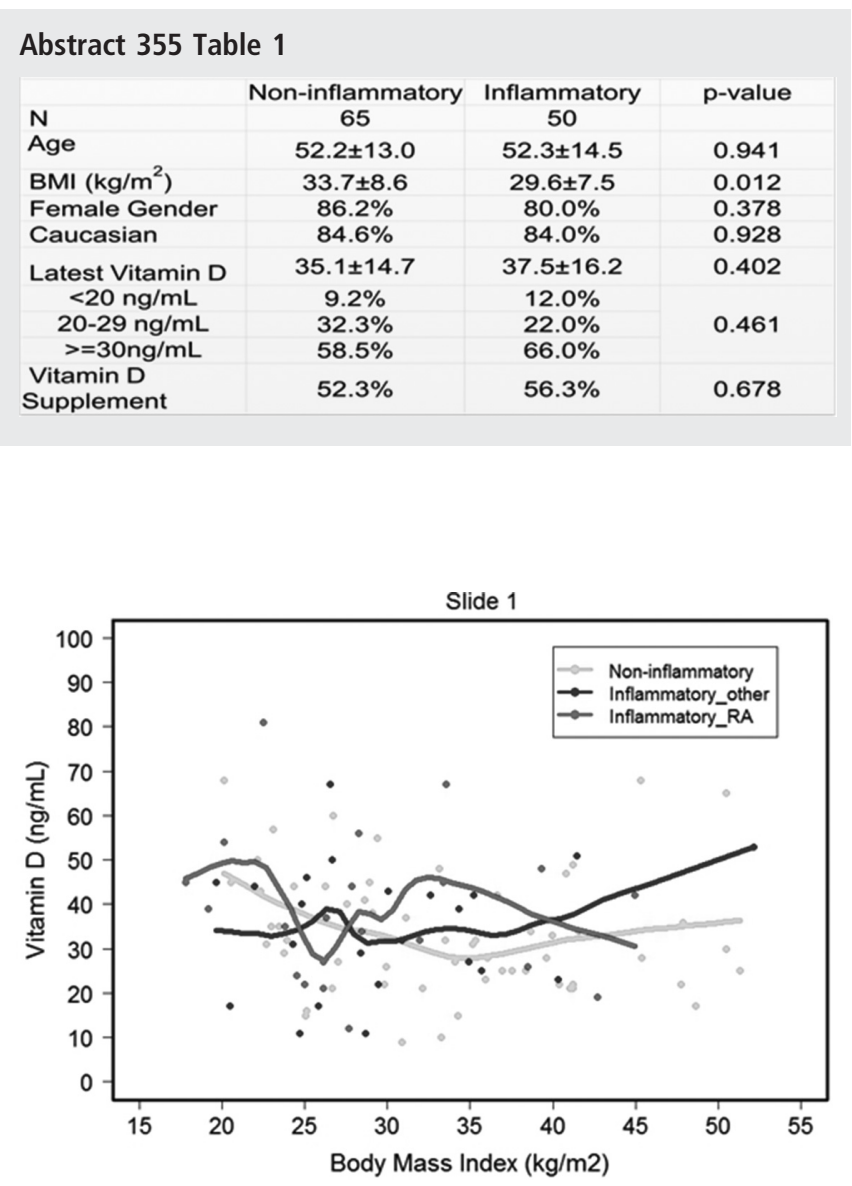

Abstract 355 Figure 1

Background and aims Studies have shown an association between levels of Vitamin D and incidence and activity of autoimmune diseases. The purpose of this study was to examine correlation between vitamin D levels in RA and SLE patients compared to controls without autoimmune disease. Our hypothesis was that low vitamin $\mathrm{D}$ is ubiquitous in the general population and not related to specific autoimmune disease.

Methods This was a retrospective, single centre, hospital-affiliated outpatient cohort study. A systematic review of the electronic medical record generated a patient list with the diagnosis codes for RA, SLE, osteoarthritis (OA) and Fibromyalgia. Vitamin D levels were characterised as follows: deficiency $(<20 \mathrm{ng} / \mathrm{mL})$, insufficiency $(20-30 \mathrm{ng} / \mathrm{mL})$ and normal $(>30 \mathrm{ng} / \mathrm{ml})$. A total of 115 patents were included, and, SAS9.3 statistical tool was used to analyse the data.

Results A total of 23 patients had RA, 27 had SLE and 65 had non-inflammatory disease (OA and fibromyalgia). There was no statistically significant difference in the vitamin D levels in RA, SLE versus the non-inflammatory group.

We did note of interest that in the RA group, a body mass index (BMI) above 35 had lower Vitamin D levels, as opposed to the lupus and control group groups.

Conclusions In our study, we found no relationship between the levels of vitamin D levels and the presence or absence of autoimmune disease. We did find a relationship between the BMI and Vitamin D levels, and this will need further study. 